\title{
Imke Graeff*
}

\section{Open Debate on Accounting for the European Public Sector}

https://doi.org/10.1515/ael-2017-0025

Published online February 21, 2017

Abstract: This article contains the proceedings of the open debate that followed the plenary panel on 'Accounting for the European Public Sector: The Ongoing Reform of European Public Sector Accounting Standards' at the international workshop on 'Which accounting regulation for Europe's economy and society?' organised under the auspices of the European Parliament in Strasbourg, on 20 May 2015.

\author{
Table of contents \\ 1 Presentation \\ 2 Under EPSAS, is the Eiffel Tower an asset or a liability? \\ 3 Under EPSAS, is the Eiffel Tower a private company?
}

Accounting for the European Public Sector: Roundtable on the Ongoing Reform of European Public Sector Accounting Standards (EPSAS)

1. "Harmonising European Public Sector Accounting Standards (EPSAS): Issues and Perspectives" by Yuri Biondi, https://doi.org/10.1515/ael-2017-0014

2. "France Supports Accrual Accounting For The Public Sector" by Marie-Pierre Calmel, https://doi.org/10.1515/ael-2017-0019

3. "Challenges for European Public Sector Accounting” by David Heald, https://doi.org/ 10.1515/ael-2017-0021

4. "Italian Public Sector Accounting Reform: A Step Towards European Public Sector Accounting Harmonisation" by Riccardo Mussari and Daniela Sorrentino, https://doi.org/ 10.1515/ael-2017-0006

5. “European Public Sector Accounting Standards (EPSAS)" by Alexandre Makaronidis, https://doi.org/10.1515/ael-2017-0008

6. "Open Debate on Accounting for the European Public Sector" by Imke Graeff, https://doi. org/10.1515/ael-2017-0025

*Corresponding author: Imke Graeff, ESCP Europe and Labex Refi, Paris, France, E-mail: imke.graeff@yahoo.com 


\section{Presentation}

This article contains the proceedings of the open debate that followed the plenary panel on 'Accounting for the European Public Sector: The Ongoing Reform of European Public Sector Accounting Standards' at the international workshop on 'Which accounting regulation for Europe's economy and society?' organised under the auspices of the European Parliament in Strasbourg, on 20 May 2015.

Identified participants comprise Yuri Biondi (Cnrs - IRISSO and Labex Refi), Alexandre Makaronidis (Project lead and head of the GFS quality management and government accounting unit at Eurostat), Shyam Sunder (Yale University).

Raised questions were: (i) Under EPSAS, is the Eiffel Tower an asset or a liability?; (ii) Under EPSAS, is the Eiffel Tower a private company?

\section{Under EPSAS, is the Eiffel Tower an asset or a liability?}

Raised by Shyam Sunder (Yale University)

Alexandre Makaronidis (Project lead and head of the GFS quality management and government accounting unit at Eurostat)

It is a very interesting question, but I do not have an answer to the question, and I think it would be also a bit arrogant for myself to answer the question. But is it really the most important one?

\section{Under EPSAS, is the Eiffel Tower a private company?}

Raised by Anonymous

Alexandre Makaronidis (Project lead and head of the GFS quality management and government accounting unit at Eurostat)

Okay ... The point is the following: What we are suggesting here is that taking IPSAS as a reference we should go through a process and agree on a common approach on what needs to be recognised, how it needs to be measured, reported and disclosed. Now, there are also more concrete questions to be answered: So does the asset have an economic use or does it generate cash? There are many ways to go about that and 
there have been also many different ways by which Member States have tried to approach the question. Okay, I think that is answer enough.

\section{Yuri Biondi (Cnrs - IRISSO and Labex Refi)}

Although it is too late to open a debate about the issue of fair value in general and in the public sector in particular, I wish adding a last quick remark, as for I spent ten years of my academic life working on fair value accounting. It is fair to say that the European Commission (EC) has already responded to the role that fair value played in the global financial crisis of 2007-08 when, late 2008, it accepted to suspend the application of fair value measurements and impairments by those financial institutions which have generated and propagated the crisis itself. Therefore, we do not have to wait for the EC forthcoming report ${ }^{1}$ about this role of fair value in the crisis, because the EC itself has already provided a clear-cut answer by doing. Thank you.

Acknowledgements: This Q\&A session on 'Accounting for the European Public Sector' was included in the international workshop on 'Which accounting regulation for Europe's economy and society?' organised under the auspices of the European Parliament in Strasbourg, on 20 May 2015, in tribute to Mr Jérôme Haas (1963-2014), first chairman of the Accounting Standards Authority of France (ANC). It was organised by the Laboratory of Excellence on Financial Regulation (Labex ReFi), which is supported by PRES heSam under the reference ANR-10-LABX-0095. It benefitted from a French government grant by the National Research Agency (ANR) under the funding program 'Investissements d'Avenir Paris Nouveaux Mondes (Investments for the future Paris - New Worlds) reference ANR-11-IDEX-0006-02.

1 European Commission (2015), Evaluation of Regulation (EC) No 1606/2002 of 19 July 2002 on the application of International Accounting Standards, $\{\operatorname{COM}(2015) 301$ final $\}$ and accompanying document SWD(2015) 120 final, Brussels, 18 June 2015. See also: Communication from the Commission to the European Parliament and the Council on Long-term financing of the European economy (COM(2014) 168 final, March 2014). 